\title{
MAKNA SUNGAI DALAM RUANG HIDUP YANG BERUBAH: STUDI KASUS DAYAK NGAJU, KALIMANTAN TENGAH
}

\author{
THE MEANING OF RIVER IN THE CHANGING CONTEXT \\ OF LIVING SPACE: A CASE STUDY OF DAYAK NGAJU, \\ CENTRAL KALIMANTAN
}

\author{
Septi Dhanik Prastiwi \\ Balai Pelestarian Nilai Budaya Provinsi Kalimantan Barat \\ Jln. Letjen Sutoyo, Pontianak Selatan, Kalimantan Barat, Indonesia \\ septi.dhanik@gmail.com
}

Diterima tanggal 26 Maret 2021

Tanggal disetujui 13 Desember 2021

\begin{abstract}
The rivers flow on the island of Borneo have had a significant function for human life since a long time ago. The river has had a role in the dynamics of civilization and environmental evolution in human life until now. With the construction of road infrastructure, the significance of rivers for riverside communities has also changed. This study sees how Ngaju people interpret the river in a living space that changes with development. The research was conducted in two villages which show the characteristics of different locations, society, and development rates. The villages are Talingke village on the bank of the Katingan River and Pangi Village on the bank of the Kahayan River. Data collection were through observation, interviews, and literature study. The study shows that the characteristics of the river area, the community, and the development rates affect the community in interpreting the river. On the one hand, Pangi people start to leave activities in the river, but they still hold the values of the river in their lives. On the other hand, Talingke's people still focus their activities on the river but no longer have river values in their lives.
\end{abstract}

Keywords: the significance of river, Ngaju people, living space, and change.

\begin{abstract}
ABSTRAK
Sungai-sungai yang membelah Pulau Kalimantan memiliki fungsi penting bagi kehidupan manusia sejak masa lalu. Sungai memiliki peran dalam dinamika peradaban dan evolusi lingkungan pada kehidupan manusia hingga sekarang. Namun seiring dengan pembangunan jalan darat, makna sungai bagi masyarakat tepian sungai mengalami perubahan. Kajian ini melihat bagaimana masyarakat Dayak Ngaju memaknai sungai dalam ruang hidup yang berubah dengan adanya pembangunan. Penelitian dilakukan pada dua desa dengan karakteristik lokasi, karakteristik masyarakat, dan laju pembangunan yang berbeda yaitu
\end{abstract}


Handep Jurnal Sejarah dan Budaya Vol. 5, No. 1, Desember 2021, hlm. 69-96

Desa Talingke yang berada di tepian Sungai Katingan dan Desa Pangi yang berada di tepian Sungai Kahayan. Pengumpulan data dilakukan dengan cara observasi, wawancara, dan studi pustaka. Hasil dari kajian ini memperlihatkan bahwa karakteristik wilayah sungai, masyarakat dan laju pembangunan mempengaruhi masyarakat dalam memaknai sungai. Di satu sisi, masyarakat Pangi mulai meninggalkan aktivitas di sungai namun mereka masih memegang nilai-nilai sungai dalam kehidupannya. Sebaliknya, masyarakat Talingke masih memusatkan aktivitasnya di sungai namun tidak lagi sepenuhnya memegang nilai-nilai sungai dalam kehidupannya.

Kata kunci : makna sungai, orang Ngaju, ruang hidup, dan perubahan.

\section{A. PENDAHULUAN}

Pulau Kalimantan memiliki sungaisungai besar seperti Sungai Kapuas dan Sungai Malawi di Kalimantan Barat, Sungai Kahayan, Sungai Mentaya atau Sungai Sampit, dan Sungai Kapuas di Kalimantan Tengah, Sungai Barito di Kalimantan Selatan, Sungai Mahakam, Sungai Kayan dan Sungai Berau di Kalimantan Timur (Hartatik 2004:141). Sungai-sungai yang membelah Pulau Kalimantan ini memiliki fungsi penting bagi kehidupan manusia sejak masa lalu. Sungai memiliki peran dalam dinamika peradaban dan evolusi lingkungan pada kehidupan manusia hingga sekarang. Demikian juga sumber daya yang ada di sekitar sungai juga mampu menghidupkan perekonomian, mendorong pertumbuhan desa dan kota bahkan mendorong kerajaan-kerajaan di bumi Kalimantan (Kasnowihardjo, Wasita, dan Andi Nuralang, eds. 2004:vii). Jejak peradaban dan evolusi tersebut dapat dilihat diantaranya dari ditemukannya kubur-kubur batu berbentuk bejana persegi di tepi Sungai Kayan, alat-alat batu neolitik berupa kapak persegi dan kapak bahu ${ }^{1}$, ditemukannya bangunan candi seperti Candi Agung dan Candi Laras yang terletak tidak jauh dari sungai $^{2}$ serta situs Kerajaan Kutai Lama, Anggana (1300-1732) yang terletak di tepian Sungai Mahakam (Hartatik 2004:143-146). Temuantemuan arkeologis di wilayah Kalimantan tersebut memperlihatkan bagaimana sejak dahulu sungai memiliki peran penting dalam kehidupan manusia.

Sebagai sebuah bentang alam, sungai memiliki beragam sumber daya yang dapat menunjang kehidupan manusia. Aliran air di sungai mempermudah manusia untuk berpindah ke tempat lain sehingga sungai memiliki peran dalam mobilitas dan persebaran masyarakat. Sumber daya yang ada di sungai juga memberikan kemungkinan

\footnotetext{
1 Alat-alat batu tersebut ditemukan di tepi Sungai Margasari, Marabahan, dan daerah pegunungan di Banjar, Rantau, Kandangan, dan Barabai Kalimantan Selatan.

2 Dalam tulisannya, Hartatik (2014:146) menyebutkan jika Candi Laras terdapat di daerah Margasari yang diapit tiga sungai yaitu Sungai Nagara, Sungai Tapin, dan Sungai Amas, sedangkan Candi Agung diapit sungai-sungai kecil yang semuanya bermuara di Sungai Nagara.
} 
bagi manusia untuk membangun kehidupan. Wilayah tepian sungai banyak digunakan sebagai tempat bermukim di mana kemudian permukiman ini berkembang menjadi lebih luas. Wijanarka (2008:1) mencatat bahwa kota-kota di Kalimantan pada dasarnya tumbuh dan berkembang dari cikal bakal pemukiman tepi sungai ${ }^{3}$. Senada dengan hal tersebut, Sunarningsih (2004:103) juga menyebutkan bahwa di Kalimantan Selatan, Kota Banjarmasin, dan Kota Martapura merupakan dua kota yang juga tumbuh dan berkembang dari tepian sungai.

Dengan wilayah yang banyak memiliki aliran sungai, permukiman tepi sungai sangat mudah dijumpai. Hartatik (2017:14) menyebutkan jika menurut cerita yang dituturkan, zaman kuno di Kalimantan ditandai perpindahan pertama orang-orang Dayak di pedalaman. Mereka berpindah dengan menyusuri sungai dan kemudian bermukim di tepi sungai. Ada pula yang masuk ke pedalaman namun masih dalam wilayah aliran sungai. Dalam tulisannya yang lain, secara lebih spesifik, Hartatik (2017:149-164) menyebutkan bagaimana persebaran suku Dayak di Kalimantan bagian tenggara dimungkinkan melalui Sungai Barito dan anak-anak sungainya.

Permukiman di tepi sungai terdapat hampir di seluruh Kalimantan baik di wilayah pedalaman maupun perkotaan. Di wilayah perkotaan yaitu wilayah Kota Banjarmasin, permukiman di tepi

\footnotetext{
3 Embrio Kota Palangkaraya dibangun di tepi Sungai Kahayan tepatnya di Kampung Pahandut yang merupakan kampung tradisional di tepi sungai.
}

sungai dapat di lihat di sepanjang Sungai Martapura sementara di wilayah Kota Samarinda, permukiman sungai berada di tepi Sungai Mahakam. Di wilayah pedalaman, menurut Hartatik, hampir semua permukiman masyarakat Dayak berada di tepi sungai seperti masyarakat Dayak Ngaju yang berada di sepanjang Sungai Mentaya, Sungai Seranau, dan Sungai Kapuas di Kalimantan Tengah; Dayak Tunjung dan Dayak Benuaq di pedalaman Sungai Mahakam Kalimantan Timur (Hartatik 2004:149).

Pembangunan permukiman masyarakat di tepian sungai merupakan salah satu bentuk adaptasi masyarakat terhadap lingkungan wilayah yang didominasi oleh hutan dan sungai. Bagi mereka yang berdiam di tepian sungai, lingkungan sungai sangat mempengaruhi aktivitas hidup mereka. Salah satunya adalah keragaman alat transportasi sungai yang dimiliki masyarakat. Seperti yang dikatakan Riwut (2007:33-34) bahwa hutan yang luas, sungai yang lebar dan panjang menyukarkan hubungan ke mana-mana sehingga di beberapa tempat, lokasi antar-kampung menjadi berjauhan. Di masa lalu hanya ada beberapa daerah yang memiliki jalan raya seperti di Banjarmasin, Hulu Sungai, Pontianak, dan Balikpapan. Di kota-kota tersebut masyarakat dapat menggunakan oto atau motor dan gerobak sepeda. Sementara itu di tempat-tempat lain seperti daerah Barito, Kapuas, Kahayan, Katingan, Hulu Mahakam, Tanah Bumbu, dan Hulu Kapuas Bohang (Kalimantan Barat) perhubungan sangat sukar karena hampir tidak ada jalan raya yang dapat dilalui 
Handep Jurnal Sejarah dan Budaya Vol. 5, No. 1, Desember 2021, hlm. 69-96

oleh oto. Sebagai pengganti jalan raya tersebut adalah sungai dengan menggunakan perahu-perahu sehingga perjalanan menjadi lambat dan membutuhkan waktu cukup lama untuk menuju udik atau tempat-tempat yang dituju. Dengan kondisi tersebut tidak heran jika transportasi sungai mendominasi kehidupan masyarakat di Kalimantan.

Riwut (2007:33) menyebutkan bahwa dahulu terdapat beragam alat transportasi seperti rangkan, tambangan (perahu beratap untuk tempat-tempat yang agak jauh), sudur, jukung patai, gondola (perahu yang dipakai berdagang, agak besar, beratap, berkamar dan di dalamnya tersedia barang dagang keperluan sehari-hari, biasanya dibuat oleh orang-orang di Nagara Kalimantan Selatan), penes, rombong (perahu kecil untuk menjual kopi dan teh), beca air (perahu kecil yang didayung dua orang untuk membawa penumpang, hilir mudik di kota-kota), dan lain-lain. Dalam perkembangannya perahu kemudian dilengkapi dengan mesin kecil yaitu motor tempel dan mesin klotok (kapal klotok) sehingga mempercepat perhubungan antar-kampung.

Tidak hanya sarana transportasi, tipologi rumah warga yang tinggal di tepian sungai menunjukkan bagaimana mereka berusaha untuk dapat mengakses sungai dengan mudah. Beberapa membangun rumah di daratan yang ada di tepian sungai tetapi ada pula yang membangun rumah lanting atau rumah di atas air. Demikian juga keberadaan alat-alat menangkap ikan di sungai juga memperlihatkan bagaimana sungai menempati peran penting dalam kehidupan masyarakat Dayak dan masyarakat tepian sungai pada khususnya.

Seiring dengan pembangunan wilayah, aktivitas di sungai tidak lagi mendominasi kehidupan masyarakat Dayak Ngaju. Pembangunan infrastruktur darat telah mengubah orientasi hidup masyarakat di mana pembangunan permukiman di dekat atau mendekati jalan raya menjadi pilihan yang paling banyak dilakukan oleh masyarakat. Kemudahan akses menjadi salah satu pertimbangan masyarakat dalam membangun kehidupannya mendekati jalan raya. Perubahan ruang hidup tersebut sedikit banyak membawa perubahan dalam hal orientasi hidup masyarakat dari yang semula berorientasi ke sungai menjadi berorientasi ke darat. Tema ini menarik karena desa-desa yang berada di tepian sungai memiliki karakteristik wilayah, karakteristik penduduk, dan laju pembangunan yang beragam sehingga tanggapan terhadap perubahan ruang hidup yang terjadi bisa jadi juga berbeda-beda. Oleh karena itu sangat menarik untuk melihat bagaimana masyarakat Ngaju di dua desa yang memiliki karakteristik wilayah, penduduk, dan laju pembangunan yang berbeda memaknai sungai dalam ruang hidup yang berubah. Kajian ini bertujuan untuk memberikan gambaran atau mendeskripsikan bagaimana masyarakat Ngaju memaknai sungai dalam ruang hidup yang telah berubah dengan melihat ketiga faktor tersebut (karakteristik wilayah, penduduk, dan laju pembangunan).

Kajian mengenai sungai-sungai di Kalimantan telah dilakukan dari 
beberapa lintas disiplin. Dari tinjauan arkeologis seperti yang dilakukan oleh para arkeolog Balai Arkeologi Kalimantan (lihat Kasnowihardjo, Wasita dan Andi Nuralang, eds. 2004). Kajian tersebut menunjukkan bahwa sungai memiliki peran penting dalam kehidupan manusia di Kalimantan sejak zaman dahulu dan hal ini dapat dibuktikan dari keberadaan candi, situs, dan peninggalan-peninggalan lainnya. Selain itu ada pula kajian yang dilakukan oleh Subiyakto dan Djoko Suryo (2001) serta Rahmayani, Yusri Darmadi, dan Andang Firmansyah (2018) yang membahas sungai dari kajian sejarah. Keduanya membahas mengenai pelayaran sungai di Kalimantan Tenggara di abad XIX dan integrasi ekonomi di Sungai Kapuas.

Berbeda dengan kajian itu, Putro dan Nurhamsah (2015), Mentayani (2019), Hamidah dkk. (2014), dan Wijanarka (2008) membahas bagaimana sungai-sungai yang ada di Kalimantan di masa kini yaitu dengan melihat pola permukiman, identitas dan eksistensi permukiman tepi sungai, model pengembangan transportasi sungai dan desain kawasan sungai agar sungai kembali menjadi riverfront. Ada pula kajian yang dilakukan oleh Purba dkk. (2020), Johansen dkk. (2017) yang sama-sama membahas mengenai budaya sungai pada masyarakat Sintang dan komunitas Dayak Pompakng.

Selain kajian-kajian tersebut terdapat juga tulisan Rochgiyanti (2011) yang melihat bahwa sungai tidak hanya berfungsi sebagai sarana transportasi air namun juga memiliki fungsi ekonomi, interaksi, dan sosialisasi. Selain kajian tersebut, kajian mengenai fungsi sungai juga dilakukan oleh penulis namun kajian yang dilakukan lebih menekankan pada perubahan fungsi sungai. Dalam kajian tersebut penulis bersama tim (Prastiwi, Ari Wahyudi, dan Jonathan Philip Thomas 2016) menyebutkan bahwa dari waktu ke waktu fungsi sungai mengalami perubahan seiring terjadinya perubahan orientasi pengelolaan sumber daya alam dari darat ke air dan perubahan nilai yang dikandung dalam sumber daya air.

Selain perubahan fungsi sungai, penulis bersama tim (Prastiwi dan Galuh Bayuardi 2017) juga mengkaji mengenai sungai dilihat dari sudut pandang kosmologi masyarakat Ngaju di Desa Pangi, Kecamatan Banama Tingang, Kabupaten Pulang Pisau. Kajian-kajian yang telah disebutkan di atas telah memberikan gambaran bagaimana kompleksnya fungsi sungai dalam kehidupan manusia tidak hanya di masa lalu namun juga di masa kini. Namun di antara tulisan-tulisan tersebut, belum banyak yang secara khusus membahas mengenai makna sungai bagi kehidupan masyarakat di Kalimantan. Fahrianoor dan Andika Sanjaya (2021) mengkaji mengenai konsep batang banyu pada masyarakat tepian sungai dengan membongkar pengalaman-pengalaman sadar masyarakat terhadap makna sungai. Dalam kajian ini disebutkan bahwa konsep batang banyu menjadi konsep yang dipahami masyarakat dan dipraktikkan dalam keseharian seperti mata pencaharian, tata laku, dan budaya rumah.

Kajian tentang makna juga dilakukan Luardini (2008). Tulisan ini tidak mengkaji sungai "secara fisik" namun justru melihat makna dan nilai sungai 
Handep Jurnal Sejarah dan Budaya Vol. 5, No. 1, Desember 2021, hlm. 69-96

dari teks legenda Dayak Ngaju. Dari kajian mengenai legenda tersebut ternyata bagi masyarakat Ngaju, sungai memiliki banyak makna seperti makna kekuatan dan kekuasaan, makna konotatif, dan makna identitas.

Dua kajian tersebut memperlihatkan bagaimana sungai memiliki makna khusus bagi kehidupan masyarakat. Untuk melengkapi kajian yang sudah ada, maka tulisan ini akan menggambarkan bagaimana masyarakat yang tinggal di tepian sungai memaknai sungai dalam ruang hidup yang berubah akibat pembangunan dengan melakukan perbandingan pada dua desa tepian sungai yang memiliki karakteristik yang berbeda.

Untuk mengetahui bagaimana masyarakat memaknai sungai dalam ruang hidup yang berubah, maka perlu diuraikan terlebih dahulu mengenai fungsi sungai bagi kehidupan masyarakat desa yang tinggal di tepian sungai. Pemaknaan terhadap sesuatu yang paling pragmatis adalah pemaknaan berdasarkan fungsi ataupun kegunaan (Prastiwi et al. 2016). Fungsi atau kegunaan dari sesuatu adalah hal yang paling dapat diamati dan mudah untuk dikonfirmasi atau dengan kata lain, penampakan atau fenomena yang paling mudah dilihat dan diamati adalah penampakan fisik. Pandangan terhadap keberadaan sungai secara fisik melibatkan dimensi kognitif yang terkait dengan pengetahuan mengenai lingkungan sekitarnya, mulai dari arti dan juga fungsi, yang diinterpretasi dari pengalaman dan pengetahuan baik dari kehidupan sehari-hari ataupun cerita dari generasi sebelumnya. Adapun untuk melihat bagaimana perubahan ruang hidup yang terjadi maka perlu dilihat kondisi ruang hidup di masa lalu dan masa kini dan faktor yang menjadikan ruang hidup tersebut berubah.

Menurut Purwanto (2010:46), perubahan kebudayaan dapat disebabkan oleh munculnya penemuan baru atau invention, difusi, dan akulturasi, serta perubahan lingkungan. Poerwanto juga menyebutkan bahwa ruang lingkup perubahan kebudayaan lebih menekankan pada sistem ide, termasuk pula mencakup perubahan dalam hal norma-norma dan aturanaturan yang dijadikan pegangan oleh warga masyarakat. Sementara itu untuk mengkaji perubahan yang terjadi dalam masyarakat, maka harus bertitik tolak dari sumber terjadinya perubahan (Roger dan Shoemaker dalam Poerwanto 2010:169-170). Dalam kajian ini akan ditekankan mengenai perubahan ruang hidup dan bagaimana masyarakat Ngaju menanggapi serta menyesuaikan diri dengan melakukan studi komparasi di dua desa yang berbeda.

\section{B. METODE}

Penelitian mengenai makna sungai di kalangan orang Ngaju ini menggunakan metode kualitatif. Pengumpulan data dilakukan pada tahun 2016, 2017, dan 2019 di dua desa yang berbeda yaitu Desa Pangi, Kabupaten Pulang Pisau, dan Desa Talingke, Kabupaten Katingan, Provinsi Kalimantan Tengah. Kedua desa ini dipilih karena memiliki karakteristik yang berbeda di mana permukiman masyarakat di Desa Talingke berada tepat di tepian Sungai Katingan dan dihuni oleh masyarakat 
Dayak Ngaju yang mayoritas memeluk agama Islam. Adapun permukiman di Desa Pangi berada di tepian Sungai Kahayan dan didiami oleh masyarakat Dayak Ngaju yang memeluk beragam agama. Meski demikian, kehidupan di desa ini masih sangat kental dengan nuansa Kaharingan karena terdapat cukup banyak pemeluk Kaharingan.

Dilihat dari topografi wilayah, Desa Talingke memiliki topografis dataran rendah sedangkan Desa Pangi memiliki topografis perbukitan sehingga akses ke sungai menjadi cukup curam. Selain perbedaan, kedua desa ini juga memiliki kesamaan yaitu pada saat ini masyarakatnya mayoritas bekerja sebagai penambang emas di sungai. Dengan karakteristik ini, akan dikaji bagaimana makna sungai di kedua masyarakat desa tersebut di masa lalu dan di masa kini untuk melihat perubahan budaya sungai yang terjadi.

Proses pengumpulan data melalui tiga cara yaitu studi pustaka, wawancara, dan observasi. Studi pustaka dilakukan dengan cara mencari sumber pustaka yang membahas mengenai sungai di Kalimantan untuk mendapat gambaran di mana kebaruan dari tulisan ini dan juga sebagai bahan analisis data. Selain studi pustaka, wawancara, dan observasi menjadi sumber utama data. Wawancara baik di Desa Talingke maupun di Desa Pangi dilakukan kepada anggota masyarakat yang selama ini pernah dan masih beraktivitas di sungai, perangkat dan tetua desa. Khusus untuk Desa Pangi, wawancara juga dilakukan kepada para basir (pemimpin upacara Kaharingan).
Pemilihan informan dilakukan dengan teknik snowball dimana informan diperoleh dari keterangan informan sebelumnya. Untuk melakukan wawancara, penulis menggunakan panduan wawancara dan dilengkapi dengan buku catatan serta alat perekam (recorder) agar pernyataan informan terdokumentasi dengan baik. Panduan wawancara yang digunakan berisi pertanyaan yang bersifat terbuka sehingga memungkinkan peneliti untuk mengembangkan pertanyaan jika ada data yang perlu didalami atau terdapat data baru yang perlu digali lebih dalam.

Untuk melihat bagaimana kehidupan masyarakat yang bermukim di tepian sungai, penulis juga melakukan observasi selama pengumpulan data di lapangan. Observasi dilakukan dengan melakukan pengamatan kondisi desa dan juga aktivitas apa saja yang dilakukan oleh masyarakat di sungai termasuk juga di dalamnya observasi terhadap akses transportasi dan pembangunan desa. Data yang sudah dikumpulkan baik berupa data wawancara ditranskripsikan dan kemudian dikategorisasikan sesuai dengan kategori-kategori yang telah disusun. Oleh karena tulisan ini berusaha untuk melihat makna sungai yang terdapat di dua desa yang berbeda maka dilakukan komparasi data dan dilanjutkan analisis untuk mengetahui bagaimana budaya sungai orang Ngaju dalam ruang hidup mereka yang telah berubah.

\section{HASIL DAN BAHASAN}

Kalimantan Tengah merupakan salah satu provinsi yang memiliki banyak sungai. Data dari BPS Kalimantan 
Handep Jurnal Sejarah dan Budaya Vol. 5, No. 1, Desember 2021, hlm. 69-96

Tengah (2021:12) ${ }^{4}$ menyebutkan jika provinsi ini memiliki 11 sungai yang dikategorikan menurut panjang, kedalaman, dan lebar. Kesebelas sungai tersebut yaitu Sungai Jelai, Sungai Arut, Sungai Lamandau, Sungai Kumai, Sungai Seruyan, Sungai Mentaya, Sungai Katingan, Sungai Sebangau, Sungai Kahayan, Sungai Kapuas, dan Sungai Barito. Melengkapi data tersebut, Rusan dkk. (2006) menyebutkan bahwa kesebelas sungai besar tersebut semuanya mengalir dari utara ke selatan dan terdapat 33 anak sungai di seluruh Kalimantan Tengah.

Berbeda dengan data di atas, Riwut (2007:3) menyebutkan jika Provinsi Kalimantan Tengah memiliki beberapa sungai yaitu Sungai Barito atau Murung dengan anak-anak Sungai Tewe, Murung, Lahei, Kumai, Arut/ Lamandau, Jelai, Kapuas, Kahayan dengan anak Sungai Sebangau, Katingan atau Mendawai, Mentaya atau Sampit, dan Sungai Pembuang atau Seruyan. Terlepas dari perbedaan data tersebut dapat dikatakan jika Kalimantan Tengah dialiri sungaisungai besar dengan anak-anak sungainya. Keberadaan sungai-sungai inilah yang kemudian digunakan oleh masyarakat untuk mengidentifikasikan ruang hidupnya.

Orang Dayak mengidentifikasikan diri dengan nama sungai tempat mereka tinggal seperti oloh Katingan dan oloh Kahayan $^{5}$. Dayak Ngaju merupakan

4 Diunduh dari Kalimantan Tengah dalam Angka Tahun 2021 pada tanggal 22 Juli 2021.

${ }^{5}$ Oloh berarti “orang” sedangkan Katingan, Kapuas, Kahayan adalah nama-nama sungai. salah satu sub-suku Dayak yang ada di Kalimantan Tengah ${ }^{6}$ dan dikenal mendiami sepanjang sungai Kapuas, Kahayan, Rungan Manuhing, Barito dan Katingan ${ }^{7}$ (Riwut 2015:18). Penamaan Ngaju sendiri berkorelasi dengan istilah yang berkaitan dengan sungai. Riwut (2015:128) menyebutkan ngaju berarti udik sementara menurut Scharer (1963:1) "Ngaju means uplander. Its probably applied to themselves in distinction from the Oloh Tumbang i.e people of the rivers mouth such as Muslim Malays and from the Ot Danum people who live at the headwaters and have settled in part of central Borneo." Dari definisi Scharer tentang asal kata ngaju ini dapat dilihat bahwa istilah ngaju digunakan untuk menyebutkan mereka yang tinggal di pedalaman Kalimantan dan merupakan penduduk asli Kalimantan. Sedangkan dalam bahasa Ngaju sendiri, ngaju berarti hulu, istilah yang digunakan untuk menyebutkan aliran air yang berasal dari tempat yang lebih tinggi, berbanding terbalik dengan istilah ngawa yang berarti hilir. Dengan dua definisi tersebut, baik Riwut maupun Scharer ingin menyebutkan bahwa orang Ngaju diidentikkan dengan

\footnotetext{
${ }^{6}$ Menurut Riwut (2015:15) suku Dayak di Kalimantan Tengah terbagi menjadi beberapa suku diantaranya adalah Manyan, Ot Danum, dan Ngaju. Namun meski terdiri atas beberapa suku, lingua franca yang digunakan adalah bahasa Ngaju.

7 Meski dikenal mendiami sungai-sungai tersebut, namun suku Dayak Ngaju tersebar di beberapa wilayah bahkan sampai ke Banjarmasin. Riwut (2015:128) lebih lanjut menyebutkan bahwa pada umumnya orang Ngaju memeluk agama Kristen Protestan, Islam, dan Kaharingan.
} 
pedalaman, baik untuk menyebutkan asal mereka maupun tempat tinggal mereka yang berasal dari pedalaman atau daerah hulu sungai.

Saat ini masyarakat Ngaju tidak lagi identik dengan mereka yang tinggal di pedalaman karena masyarakat Ngaju tinggal menyebar tidak hanya di daerah hulu namun juga menyebar di daerah hilir. Meski demikian, masih dapat ditemukan dengan mudah masyarakat Ngaju yang bermukim di tepian sungai diantaranya adalah Desa Pangi dan Desa Talingke. Kedua desa ini berada di dua wilayah kabupaten yang berbeda dan memiliki karakteristik wilayah yang berbeda pula sehingga menarik untuk melihat bagaimana mereka memaknai sungai dalam ruang hidup yang berubah.

\section{Masyarakat Tepian Sungai di Dua Desa}

\section{a. Desa Talingke}

Desa Talingke berada di Kecamatan Tasik Payawan, Kabupaten Katingan dan berada di DAS Katingan tepatnya berada di bagian hilir sungai. Menurut salah satu tetua warga yaitu Pak Esna ${ }^{8}$ yang diwawancarai pada 19 Maret 2016 di Desa Talingke, cikal bakal desa Talingke berasal dari sebuah kampung yang terletak di bagian hilir lokasi desa saat ini. Warga kampung hidup tenang hingga datangnya wabah penyakit cacar dan dilanjutkan dengan wabah muntaber yang memakan banyak korban jiwa. Kejadian ini mendorong warga untuk melakukan ritual manajah antang atau meminta petunjuk burung

\footnotetext{
${ }^{8}$ Wawancara dengan Pak Esna mantan Kepala Desa Talingke.
}

antang dalam memilih lokasi kampung yang baru. Sesuai petunjuk dari burung antang maka kemudian warga kampung membangun rumah di bagian hulu kampung lama (masih berada di tepian sungai). Di lokasi yang baru ${ }^{9}$ semakin lama penduduk kampung tersebut semakin bertambah banyak dan menjadi kampung besar sehingga kemudian di tahun 1920 dipilihlah seorang kepala kampung. Kampung inilah yang kemudian berkembang dan saat ini dikenal dengan Desa Talingke.

Di tahun 2016, warga Desa Talingke berjumlah 617 jiwa $^{10}$. Dari jumlah tersebut 611 orang beragama Islam sedangkan 6 orang beragama Kristen. Rata-rata masyarakat Dayak yang tinggal di bagian hilir Sungai Katingan memeluk agama Islam. Warga Talingke sendiri mengidentifikasikan dirinya dengan sungai di mana mereka tinggal yaitu Dayak Katingan meski mereka menggunakan bahasa Ngaju sebagai bahasa sehari-hari ${ }^{11}$.

\footnotetext{
${ }^{9}$ Kampung lama yang ditinggalkan disebut dengan kaleka dan saat ini dijadikan lokasi pemakaman warga desa. Semua lokasi kampung lama berada tepat di tepian Sungai Katingan.

${ }^{10}$ Data ini bersumber dari Daftar Isian Desa 2016. Menurut data Tasik Payawan dalam angka tahun 2020, berdasar data tahun 2018, jumlah penduduk Desa Talingke 510 orang yang terdiri dari 274 orang laki-laki dan 236 orang perempuan (sumber BPS katingankab.bps.go.id).

11 Terdapat perbedaan bahasa antara daerah hulu dengan hilir. Di wilayah hulu, menurut informan, mereka menggunakan bahasa Ot Danum yaitu bahasa Kadori sedangkan di wilayah hilir cenderung menggunakan bahasa Kahayan atau Ngaju.
} 
Handep Jurnal Sejarah dan Budaya Vol. 5, No. 1, Desember 2021, hlm. 69-96

Permukiman warga Desa Talingke tepat berada di tepian Sungai Katingan. Di Desa Talingke, rumah-rumah dibangun di sepanjang sungai dan beberapa rumah dibangun agak ke arah darat karena keterbatasan lahan di tepian sungai. Semua rumah dihubungkan dengan jalan desa berupa jembatan/ titian kayu yang terbuat dari kayu ulin dan membentang sepanjang $1,3 \mathrm{~km}$.

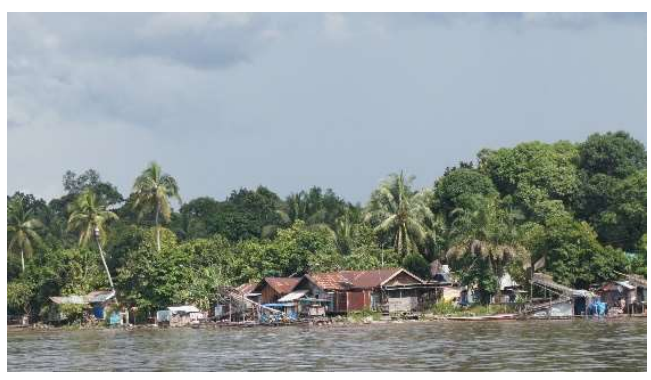

Gambar 1. Permukiman warga Talingke. Sumber: dokumentasi penulis.

Permukiman yang berada tepat di tepian sungai mempermudah warga mengakses sungai. Untuk beraktivitas di sungai, warga membangun batang ${ }^{12}$ yang dilengkapi dengan bilik kecil sebagai jamban dan mesin air yang disambungkan ke rumah dengan pipa atau selang. Di tempat ini warga beraktivitas di sungai mulai mandi,

${ }^{12}$ Batang bisa diartikan untuk menyebut sungai dan juga bisa menjadi istilah untuk menyebutkan rakit yang diletakkan ditepi sungai yang digunakan sebagai MCK dan tempat menambatkan perahu. Batang biasanya terbuat dari gelondongan kayu yang mengapung dan seringkali dilengkapi dengan lantai papan. Untuk menghubungkan dengan darat, rakit dilengkapi dengan papan atau gelondongan kayu sebagai titian. Selain itu batang juga berfungsi menjadi tempat perhentian transportasi air seperti kelotok, longboat atau kapal yang hendak singgah. Ukuran batang berbeda-beda tergantung pemilik rumah. Terkadang satu batang dipakai oleh beberapa keluarga. mencuci, memancing ikan, dan berinteraksi dengan orang lain. Kapalkapal dagang yang rutin berlabuh di batang menjadi tempat bagi warga untuk membeli kebutuhan hidup seharihari hingga kebutuhan perabotan rumah seperti seperangkat meja kursi, lemari, kursi, dan perabotan rumah lainnya. Tidak ada pasar di desa ini sehingga semua kebutuhan warga diperoleh dari kapal dagang, warung di desa dan belanja ke kota. Batang juga menjadi tempat untuk menambatkan $c e s^{13}$ dan tempat menunggu taksi air. Aktivitas masyarakat di batang menjadi pemandangan yang mudah dilihat di desa ini.

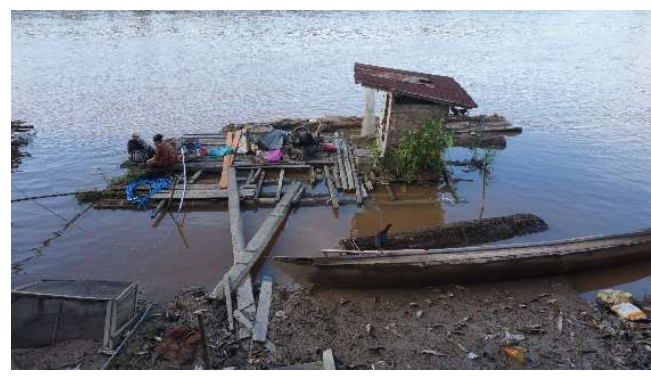

Gambar 2. Aktivitas warga di batang. Sumber: dokumentasi penulis.

Sungai Katingan hingga saat ini masih digunakan warga dalam melakukan mobilitas. Lalu-lalang petani rotan dan karet menuju ke kebun dengan menggunakan ces merupakan pemandangan sehari-hari di sungai. Sungai juga diandalkan warga dalam melakukan mobilitas ke tempat lain.

\footnotetext{
${ }^{13}$ Ces adalah kapal motor tempel yang terbuat dari kayu dengan panjang bervariasi dengan lebar 1 meter. Pada bagian belakang ces dipasang mesin tempel (5-10 PK) yang bisa dibongkar pasang. Ces merupakan transportasi harian penduduk yang tinggal di pinggir sungai untuk beraktivitas (ke ladang, memancing, menjala ikan dll).
} 
Jalur perjalanan dari desa menuju Kasongan, ibu kota kabupaten dapat ditempuh melalui dua jalur yaitu darat dan air. Jika melalui jalur air atau sungai maka dapat ditempuh dengan menggunakan taksi air berjadwal ${ }^{14}$ yang melayani rute Desa Telaga di Kecamatan Kamipang-Kasongan dan ditempuh selama 2,5-3 jam dengan biaya Rp100.000. Sementara untuk menuju kota kecamatan dapat ditempuh menggunakan ces milik sendiri dengan biaya Rp50.000 (untuk membeli bahan bakar) dan Rp150.000 jika carter (bisa PP atau pulang pergi) dengan waktu tempuh 1,5 jam. Jika melalui jalan darat, jarak dari jalan poros ke Kasongan hanya ditempuh dalam waktu 1 jam.

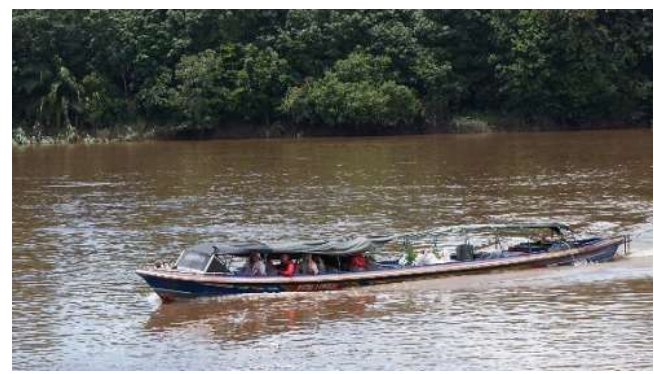

Gambar 3. Taksi air di Sungai Katingan. Sumber: dokumentasi penulis.

Akses jalan darat sebenarnya sudah ada di Desa Talingke. Di belakang permukiman warga terdapat jalan darat berupa jalan tanah sepanjang $\pm 2000 \mathrm{~m}$ yang dibangun sejak tahun 1993-1998. Sebagian jalan ini berada

${ }^{14}$ Di tahun 2016, taksi air hanya beroperasi tiap Selasa, Kamis, dan Sabtu. Taksi air ini melayani transportasi warga yang berada di hulu Desa Talingke yaitu Desa Telaga di Kecamatan Kamipang. Oleh karena rute taksi air menuju ibukota kabupaten melewati Talingke sehingga taksi air ini dimanfaatkan warga sebagai sarana transportasi. tepat di belakang permukiman warga dan sebagian lagi berada di jalan poros (sebutan warga untuk jalan ini) yang dikelilingi oleh hamparan kebun dan tanah warga. Di ujung jalan poros terdapat jalan lintas yang dahulu dibangun untuk menghubungkan desa ini dengan desa lain (pusat kecamatan) namun pembangunannya tidak dilanjutkan tanpa ada alasan jelas dari pemerintah $^{15}$.

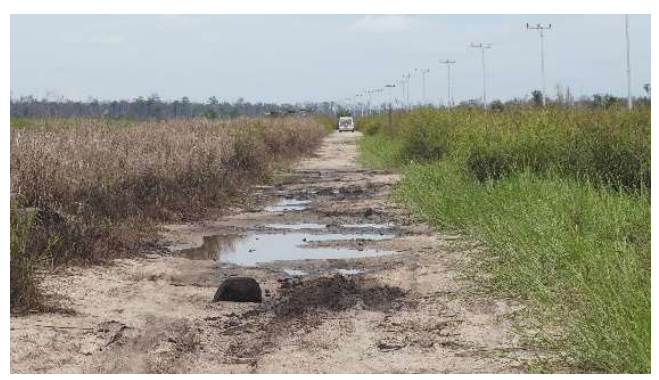

Gambar 4. Jalan desa menuju jalan lintas. Sumber: dokumentasi penulis.

Kondisi pembangunan jalan yang belum sempurna menjadikan jalan ini hanya bisa dilalui kendaraan bermotor (mobil atau motor) pada musim kemarau. Jika musim hujan tiba, masyarakat desa yang ingin menggunakan sepeda motor harus menggunakan gethe ${ }^{16}$ dari desa

15 Pembangunan jalan lintas justru mengarah ke desa lain yang terletak lebih di bagian hulu desa Talingke

${ }^{16}$ Gethek adalah sebutan untuk transportasi lokal yang biasa digunakan ketika musim hujan tiba. Gethek terbuat dari dua ces yang dijadikan satu dan diberi lantai di bagian tengah untuk mengangkut barang, motor dan penumpang. Dari desa hingga ke jalan poros ditempuh dalam waktu 30 menit melalui sungai dan parit besar. Gethek dikemudikan oleh satu orang di bagian belakang. Untuk melayani penumpang, ada beberapa gethek yang beroperasi dan biasanya saling bergantian satu sama lain. Transportasi ini melayani penumpang hingga malam hari. 
Handep Jurnal Sejarah dan Budaya Vol. 5, No. 1, Desember 2021, hlm. 69-96

dengan melalui sungai dan kemudian masuk ke kanal atau parit besar membentang sepanjang jalan menuju jalan poros. Penggunaan moda transportasi gethek diperlukan karena jalan tersebut tergenang air cukup dalam sehingga tidak memungkinkan untuk dilewati kendaraan bermotor. Sesampainya di jalan poros, perjalanan dapat dilanjutkan kembali dengan menggunakan sepeda motor pribadi atau angkutan umum.

Dibandingkan dengan akses air, jalan darat dirasakan warga jauh lebih murah dan lebih cepat. Jalan darat ini baru mulai sering diakses masyarakat sejak tahun $2014^{17}$, seiring dengan maraknya pertambangan emas di Desa Talingke. Selama ini warga Talingke mengandalkan sumber daya darat sebagai sumber mata pencaharian yaitu sebagai petani rotan dan karet. Harga rotan dan karet yang terus turun mendorong masyarakat beralih ke pekerjaan lain yaitu menjadi penambang emas sebagai sumber mata pencaharian.

Sejak menjadikan pertambangan emas sebagai sumber penghidupan, sungai tidak lagi memiliki fungsi sebagai pusat aktivitas warga namun memiliki nilai lain yaitu nilai ekonomi. Hasil dari menambang emas menjadikan masyarakat memiliki kemampuan untuk membeli sepeda motor dan bahkan ada beberapa yang memiliki mobil. Sejak masyarakat memiliki kendaraan bermotor, mobilitas ke kota

17 Aktivitas pertambangan emas di Desa Talingke dimulai sejak tahun 2011 dan baru marak di tahun 2014 dimana 90\% warga bermata pencaharian sebagai penambang emas. kecamatan atau ke kota kabupaten bahkan ke tempat-tempat lain lebih banyak dilakukan melalui darat. Meski demikian secara umum masyarakat Desa Talingke masih mengandalkan sungai sebagai tempat beraktivitas dan sebagai sarana mobilitas karena pembangunan infrastruktur jalan darat yang belum sempurna. Mobilitas melalui sungai masih dilakukan terutama bagi warga yang hendak menuju kebun karet/rotan. Selain itu bagi warga yang tidak memiliki kendaraan bermotor mereka tetap menggunakan transportasi air yang ada seperti ces dan taksi air ${ }^{18}$ untuk menuju ke tempat lain.

\section{b. Desa Pangi}

Desa Pangi merupakan salah satu desa yang ada di Kecamatan Banama Tingang, Kabupaten Pulang Pisau. Desa ini berada di DAS Kahayan tepatnya di Sungai Kahayan bagian tengah ${ }^{19}$. Sebelum berada di lokasi yang sekarang, menurut sejarah desa, lokasi desa berpindah-pindah namun tetap berada di DAS Kahayan. Sebagai lokasi awal, cikal bakal desa Pangi berlokasi di kalek ${ }^{20}$ Pangi $^{21}$. Dorongan ingin

18 Taksi air masih menjadi andalan bagi desadesa di bagian hulu Sungai Katingan sehingga masyarakat Desa Talingke masih bisa naik taksi air untuk menuju kota kecamatan atau tempat lain.

${ }^{19}$ Wilayah Sungai Kahayan dibagi menjadi tiga yaitu hilir, tengah, dan hulu. Desa Pangi berada di bagian tengah Sungai Kahayan.

${ }^{20}$ Kaleka merupakan sebutan untuk lokasi permukiman lama (bekas permukiman) yang biasanya ditandai dengan keberadaan pohon buah-buahan.

${ }^{21}$ Kaleka Pangi berada di bagian hulu Desa Pangi yang sekarang. 
berkumpul dengan warga lain karena jumlah warga yang sedikit, mereka berpindah ke kaleka Betang yang terletak di seberang sungai Kahayan. Dari kaleka Betang, warga berpindah lagi ke Pukung Diwung (masih di seberang sungai). Dari Pukung Diwung warga berpindah ke seberang sungai Kahayan yaitu ke kaleka Nagara yang berada di sebelah hulu pemakaman lokasi desa yang sekarang (tepatnya di muara Sungai Beringen). Perpindahan ini didorong karena sungai kecil yang menjadi tumpuan sumber air warga mati.

Dari kaleka Nagara, warga kemudian bergeser lebih ke hilir yaitu ke Pangi Labehu Garantung yang merupakan lokasi Desa Pangi saat ini. Dilihat dari sejarah lokasi desa, permukiman yang dibuat warga selalu tidak jauh dari sungai. Bahkan matinya aliran sungai dapat menjadi pendorong warga desa untuk memindahkan perkampungan mereka.

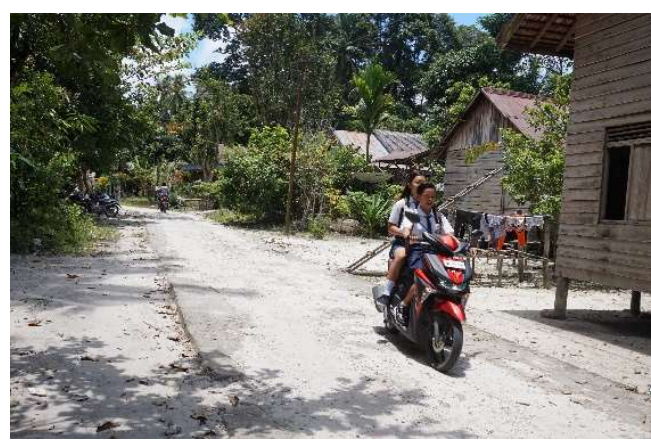

Gambar 5. Permukiman warga Pangi bawah Sumber: dokumentasi penulis.

Desa Pangi saat ini ditinggali oleh beragam suku bangsa dengan mayoritas penduduk merupakan suku Dayak Ngaju. Menurut data Daftar Isian Potensi Desa dan Kelurahan tahun 2018, penduduk Pangi berjumlah 736 jiwa. Dari jumlah tersebut masyarakat Pangi terdiri dari 4 pemeluk agama yaitu Kristen sebanyak 315 orang, agama Hindu (Kaharingan) ${ }^{22} 248$ orang, agama Islam 154 orang, dan agama Katholik 19 orang. Banyaknya pemeluk Kaharingan di desa menjadikan nuansa Kaharingan sangat terlihat di desa ini. Keberadaan Balai Basarah, sandung, sapundu ${ }^{23}$, dan upacara-upacara keagamaan yang rutin digelar menjadi bukti bahwa nuansa Kaharingan cukup kental terasa. Bahkan desa ini juga memiliki 6-7 basir yang aktif berperan dalam pelaksanaan ritual tidak hanya di tingkat desa tetapi hingga keluar desa.

Secara topografis, berbeda dengan Desa Talingke yang berada di dataran rendah, lokasi Desa Pangi meski berada di tepi sungai namun terletak di dataran yang cukup tinggi sehingga akses ke sungai tidak semudah akses masyarakat Talingke. Untuk menuju ke sungai harus melalui jalan setapak yang curam dengan jarak $\pm 200 \mathrm{~m}$ dari rumah warga. Bahkan karena posisinya yang cukup curam serta daratan atau tanah di tepi sungai cukup lebar untuk ditumbuhi pepohonan besar dan semak menjadikan sungai nyaris tidak terlihat dari jalan desa. Kondisi desa yang berada di wilayah yang cukup tinggi ini men-

\footnotetext{
22 Masyarakat Pangi meski di KTP tercatat sebagai pemeluk Hindu namun pada kenyataannya mereka pemeluk agama asli yang sering disebut dengan Kaharingan.

23 Balai Basarah merupakan tempat beribadah bagi pemeluk Hindu Kaharingan, Sapundu adalah patung menyerupai manusia yang digunakan untuk menambatkan hewan korban pada saat Upacara Tiwah, sedangkan Sandung adalah tempat tulang belulang orang meninggal yang telah ditiwahkan.
} 
Handep Jurnal Sejarah dan Budaya

jadikan Desa Pangi terbebas dari banjir. Menurut keterangan Kusnadi, salah satu warga Desa Pangi yang diwawancarai tanggal 16 Maret 2017, di saat desadesa lain di bagian hulu Desa Pangi seperti Desa Tangkahen dan desa-desa lain terkena banjir besar, Desa Pangi terbebas dari banjir.

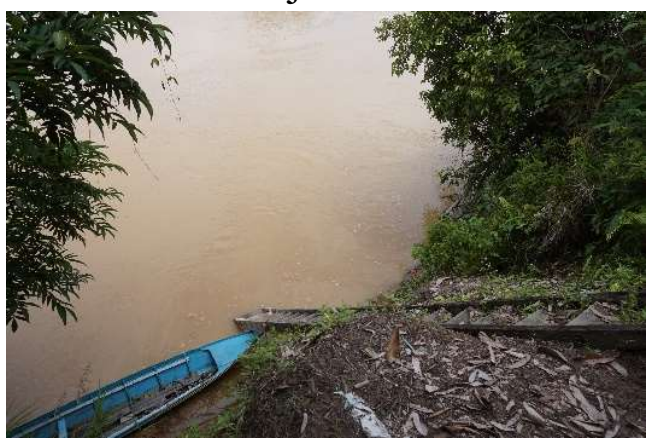

Gambar 6. Akses menuju sungai. Sumber: dokumentasi penulis.

Di masa lalu sebelum adanya pembangunan jalan lintas, sama dengan karakteristik warga tepian sungai lainnya, masyarakat Pangi juga mengandalkan sungai dalam kehidupannya. Sungai Kahayan menjadi tempat beraktivitas warganya seperti mandi, mencuci dan tempat kakus (MCK), menangkap ikan, sumber air bersih, sumber protein, dan lain sebagainya. Selain itu warga juga mengandalkan sungai sebagai jalur transportasi baik menuju ke kebun-kebun karet yang berada di seberang sungai maupun untuk menuju ke tempat lain dengan menggunakan transportasi publik atau taksi air seperti speedboat atau longboat.

Namun kini aktivitas masyarakat Desa Pangi di sungai hanya dimonopoli oleh kegiatan para penambang emas yang lalu-lalang menuju ke lantinglanting untuk menambang emas. Aktivitas lalu-lalang ces di sungai akan
Vol. 5, No. 1, Desember 2021, hlm. 69-96

sedikit lebih ramai ketika hari pasar $^{24}$ tiba. Di saat itu warga dari desa-desa di hulu sungai akan datang untuk berbelanja.

Pembangunan jalan lintas Palangkaraya-Kuala Kurun yang membelah wilayah Desa Pangi menjadikan masyarakat desa ini mulai meninggalkan "sungai secara fisik". Jejak aktivitas warga di sungai berupa jamban/batang tidak lagi dapat ditemukan. Aktivitas sehari-hari di sungai seperti MCK, mencari ikan, dan lalulalang transportasi umum sungai seperti taksi air atau speed boat tidak lagi dapat dilihat di sungai besar (Kahayan). Demikian halnya dengan pemenuhan kebutuhan air bersih dan kebutuhan pangan semua tidak lagi mengandalkan sungai. Seiring dengan keberadaan jalan lintas, aliran listrik juga mulai masuk ke desa. Aliran listrik tersebut memungkinkan bagi warga untuk memenuhi kebutuhan air bersih dengan memanfaatkan mesin air untuk mengalirkan air dari mata air ke rumah-rumah.

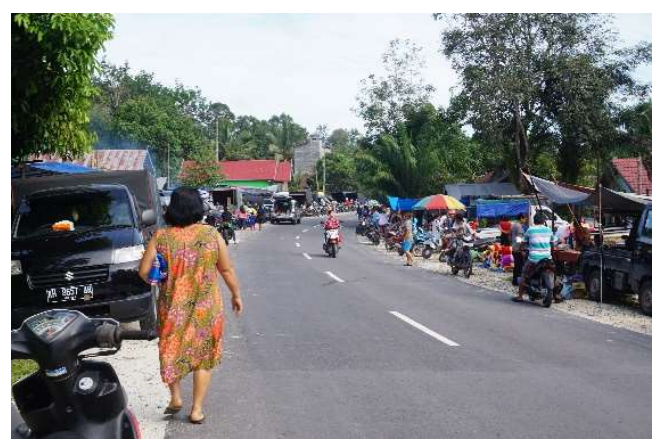

Gambar 7. Pasar desa di tepi jalan lintas. Sumber: dokumentasi penulis.

Hal yang sama terjadi dengan pemenuhan kebutuhan pangan dan kebutuhan rumah tangga lainnya. Jika

\footnotetext{
${ }^{24}$ Hari pasar di desa ini jatuh pada setiap Rabu berlokasi di pinggir jalan lintas.
} 
dahulu warga Pangi mengandalkan kapal dagang yang lalu lalang di sungai dan pasar tiban yang digelar di tepi sungai kini kebutuhan tersebut dicukupi dengan keberadaan pasar desa yang hadir di pinggir jalan lintas setiap hari Rabu. Bukan hanya pasar, kebutuhan harian masyarakat juga dapat dipenuhi dari para pedagang sayur dan lauk yang berkeliling menggunakan sepeda motor. Sedangkan untuk kebutuhan rumah tangga non-pangan, masyarakat dapat membeli dari toko-toko yang dibangun di tepi jalan lintas atau membeli dari mobil pick up pedagang yang berkeliling dari desa ke desa. Keberadaan jalan lintas menjadikan warga memiliki banyak pilihan dalam memenuhi kebutuhan hidup.

Masyarakat Ngaju di Desa Pangi tidak lagi sepenuhnya berorientasi ke sungai "secara fisik". Pemandangan aktivitas sehari-hari masyarakat di sungai tidak lagi menjadi pemandangan yang bisa ditemui seperti halnya pemandangan yang terlihat pada masyarakat yang tinggal di tepian sungai pada umumnya. Satu-satunya aktivitas warga Pangi yang masih dapat dilihat di sungai adalah aktivitas PETI $^{25}$ yang sudah mulai dilakukan sejak tahun 1990 an. Jajaran lanting penambang emas dapat dengan mudah ditemukan di Sungai Kahayan. Hasil dari menambang emas bisa dilihat dari kondisi rumah-rumah warga yang terbuat dari beton dan kepemilikan kendaraan (motor dan mobil). Beberapa tahun belakangan ini pertambangan emas tidak lagi menyasar sungai namun lahan-lahan karet dan rotan warga ${ }^{26}$.

\begin{tabular}{|c|c|c|}
\hline $\begin{array}{c}\text { Karakteristik Lokasi } \\
\text { dan Fungsi Sungai }\end{array}$ & Desa Talingke & Desa Pangi \\
\hline Nama Sungai & Sungai Katingan di Kabupaten Katingan & $\begin{array}{l}\text { Sungai Kahayan di Kabupaten } \\
\text { Pulang Pisau }\end{array}$ \\
\hline Topografi & Dataran rendah & Dataran tinggi/bukit \\
\hline Akses ke sungai & $\begin{array}{l}\text { Mudah (tepat berada di depan pemukiman } \\
\text { warga) }\end{array}$ & $\begin{array}{l}\text { Cukup sulit (harus melalui titian } \\
\text { curam dan tinggi) }\end{array}$ \\
\hline Kondisi pemukiman & $\begin{array}{l}\text { - Tepat berada di tepi sungai, } \\
\text { - Permukiman berjajar di sepanjang tepian } \\
\text { sungai } \\
\text { - Pengembangan permukiman ke arah } \\
\text { belakang pemukiman tepi sungai }\end{array}$ & $\begin{array}{l}\text { - Agak jauh dari sungai, } \\
\text { - pemukiman lama dibangun } \\
\text { menghadap sungai dan beberapa } \\
\text { dibangun di belakangnya } \\
\text { - pengembangan pemukiman saat } \\
\text { ini lebih banyak mendekati jalan } \\
\text { raya }\end{array}$ \\
\hline $\begin{array}{l}\text { Keberadaan batang } \\
\text { (jamban) di sungai }\end{array}$ & Masih mudah ditemui & Tidak ada lagi \\
\hline Sarana mobilitas & $\begin{array}{l}\text { - Ces, speedboat, taksi air, kapal dagang } \\
\text { - Menuju ke tempat-tempat lain seperti } \\
\text { kota, kecamatan, atau desa-desa lain } \\
\text { - Ke kebun yang terletak jauh dan atau } \\
\text { berada di seberang kampung } \\
\text { - Ke lokasi penambangan emas }\end{array}$ & $\begin{array}{ll}\text { - } & \text { Ces } \\
\text { - } & \text { Menuju ke kebun yang berada di } \\
& \text { seberang sungai } \\
\text { - } & \text { Ke lokasi penambangan emas }\end{array}$ \\
\hline $\begin{array}{l}\text { Aktivitas sehari-hari di } \\
\text { sungai }\end{array}$ & MCK (mandi, cuci, kakus) & $\begin{array}{l}\text { MCK dilakukan di rumah, sebagian } \\
\text { kecil warga masih mandi di anak- } \\
\text { anak sungai }\end{array}$ \\
\hline
\end{tabular}

${ }^{25}$ Pertambangan emas tradisional. Di wilayah Pangi, aktivitas PETI dimulai sejak tahun 1990 an.

${ }^{26}$ Kandungan emas di sungai dirasakan mulai berkurang sehingga mereka menyaras ke kebun karet. Kondisi ini juga mendorong 
Handep Jurnal Sejarah dan Budaya Vol. 5, No. 1, Desember 2021, hlm. 69-96

\begin{tabular}{|l|l|l|}
\hline Sumber protein & $\begin{array}{l}\text { - Menangkap ikan (memancing, menjala) } \\
\text { - Membeli ikan dari sesama warga }\end{array}$ & $\begin{array}{l}\text { Membeli di pasar atau membeli di } \\
\text { pedagang keliling }\end{array}$ \\
\hline Sumber air & $\begin{array}{l}\text { - Berasal dari air sungai yang dialirkan } \\
\text { dengan mesin pompa air dan selang } \\
\text { - Air sumur bor }\end{array}$ & $\begin{array}{l}\text { Berasal dari mata air yang dialirkan } \\
\text { ke rumah-rumah dengan mesin air } \\
\text { dan selang }\end{array}$ \\
\hline Sumber ekonomi & - Budidaya ikan (karamba) & $\begin{array}{l}\text { Kandungan emas di sungai menjadi } \\
\text { sumber mata pencaharian utama } \\
\text { warga }\end{array}$ \\
& $\begin{array}{l}\text { - Tempat untuk menyimpan rotan dan } \\
\text { karet sebelum diambil dengan kapal oleh } \\
\text { pengepul }\end{array}$ & \\
& - Kandungan emas di sungai menjadi \\
& sumber mata pencaharian utama warga & \\
\hline
\end{tabular}

Tabel 1. Karakteristik lokasi dan fungsi sungai pada Desa Talingke dan Pangi. Sumber: Olah data lapangan.

Dari uraian yang telah dijelaskan di atas, dapat dilihat bahwa terdapat perbedaan karakteristik lokasi dan fungsi sungai pada kedua desa tersebut.

Berdasarkan tabel di atas dapat dilihat jika masyarakat Ngaju di Desa Talingke lebih berorientasi ke sungai "secara fisik". Mereka memusatkan seluruh aktivitas sehari-hari di sungai dan masih mengandalkan sungai sebagai sumber daya untuk memenuhi kebutuhan hidup mereka. Sementara di Pangi, aktivitas di sungai hanya didominasi oleh kegiatan pertambangan emas. Sebagai sumber ekonomi, emas menjadi faktor penting bagi perekonomian di dua desa dan dalam merespon perubahan ruang hidup yang terjadi.

\section{Pembangunan dan Ruang Hidup yang Berubah}

Seiring dengan pembangunan, ruang hidup masyarakat tepian sungai ikut mengalami perubahan. Namun meski sama-sama telah tersentuh oleh pembangunan, tanggapan kedua masyarakat

beberapa warga untuk menginvestasikan penghasilan yang diperoleh dengan membangun sarang burung walet dengan harapan bisa menjadi alternatif sumber penghasilan selain emas. tepian sungai terhadap perubahan ruang hidup tersebut ternyata berbeda.

Laju pembangunan-dalam hal ini pembangunan jalan raya-telah menyentuh desa-desa yang terletak di tepian sungai. Desa Pangi dan Desa Talingke merupakan dua desa yang ikut merasakan keberadaan pembangunan jalan lintas (raya). Hanya saja laju pembangunan yang berbeda menjadikan masyarakat di kedua desa menanggapi perubahan ruang hidup yang dialami dengan cara berbeda.

Pembangunan jalan lintas Palangkaraya-Kuala Kurun memberikan dampak yang besar bagi kehidupan warga Desa Pangi. Sebagai jalan lintas yang menghubungkan antara pusat provinsi dengan kabupaten lain, pembangunan jalan ini sangat menguntungkan bagi masyarakat Pangi. Pembangunan jalan yang melintasi wilayah Desa Pangi tidak hanya membuka dan mempermudah akses masyarakat untuk menuju ke kota atau kabupaten lain namun juga diikuti dengan pengadaan fasilitas umum seperti ketersediaan jaringan listrik ${ }^{27}$.

27 Jaringan listrik mempermudah warga mendapatkan air bersih dengan cara memanfaatkan mesin air untuk mengalirkan air dari sumber mata air ke rumah-rumah. 
Pemerintah desa menanggapi pembangunan jalan lintas ini dengan membangun sarana dan prasarana desa seperti kantor desa, pusat kesehatan, sarana peribadahan di tepi jalan raya. Selain fasilitas milik desa, keberadaan jalan raya juga mendorong pembangunan fasilitas umum lain seperti fasilitas pendidikan ${ }^{28}$. Keberadaan jalan lintas juga membuka peluang ekonomi bagi masyarakat. Warga yang memiliki tanah di sekitar jalan lintas tidak hanya membangun rumah di tepi jalan namun juga membangun toko kelontong, warung makan, toko bangunan dan sebagainya. Bukan hanya itu, pemenuhan kebutuhan masyarakat yang pada awalnya mengandalkan hilir mudik kapal dagang di sungai, kini dapat merasakan kehadiran pasar yang terletak di tepi jalan lintas. Setiap hari Rabu, para pedagang dari kota dan daerah sekitar datang menghidupkan pasar tersebut. Meski tidak dilengkapi bangunan/kios pasar dan hanya berupa bangunan semi permanen namun keberadaan pasar tidak hanya membantu warga Pangi mendapatkan kebutuhan hidup sehari-hari namun juga membantu warga desa tepian sungai dari hulu mendapatkan barang kebutuhan ${ }^{29}$.

28 Sebelum ada jalan raya, hanya ada bangunan sekolah yang dibangun menghadap ke sungai. Saat ini bangunan sekolah dibangun berada cukup jauh di seberang jalan lintas. Bangunan sekolah tersebut merupakan sekolah terpadu yang terdiri dari sekolah dasar, sekolah menengah pertama, dan sekolah kejuruan.

${ }^{29}$ Setiap hari pasar, warga desa yang berada di hulu Desa Pangi berdatangan ke Desa Pangi untuk berbelanja. Banyak dari mereka menggunakan ces sebagai alat transportasi menuju Desa Pangi.
Pembangunan jalan lintas telah mengubah wajah Desa Pangi yang awalnya merupakan desa tepian sungai menjadi desa yang lebih berorientasi ke jalan raya (darat). Pembangunan yang dilakukan baik oleh pemerintah maupun masyarakat cenderung mengarah menjauhi sungai. Saat ini, jalan lintas telah membagi wilayah desa menjadi dua yaitu wilayah bawah (berada di tepian sungai) dan wilayah atas (berada di seberang jalan lintas).

Hal yang berbeda terjadi di Desa Talingke. Pembangunan jalan raya yang pada awalnya diarahkan menuju wilayah Desa Talingke ternyata justru diarahkan menuju ke desa lain sehingga akses untuk menuju Desa Talingke belum sepenuhnya terbuka. Jalan raya yang diharapkan membuka akses warga Talingke ternyata masih jauh dari harapan. Pembangunan jalan yang belum sepenuhnya selesai menjadikan masyarakat Desa Talingke tetap bertahan dengan kondisi yang ada. Selain pembangunan jalan yang mangkrak, fasilitas listrik yang diharapkan bisa menerangi desa juga tidak kunjung terwujud. Tiang listrik yang sudah dibangun di sepanjang jalan poros belum juga dialiri listrik. Sampai tahun 2016, masyarakat Talingke masih mengandalkan mesin genset dan lampu minyak sebagai sumber penerangan.

Tidak seperti pembangunan di Desa Pangi, pembangunan Desa Talingke cenderung stagnan. Hampir seluruh sarana dan prasarana desa seperti tempat ibadah, sekolah dasar, dan pusat kesehatan masih berlokasi di tepian sungai. Hanya ada bangunan baru yang dibangun di tepi jalan poros yaitu sekolah satu atap. Keberadaan jalan 
Handep Jurnal Sejarah dan Budaya Vol. 5, No. 1, Desember 2021, hlm. 69-96

raya tidak membuat wajah Desa Talingke mengalami perubahan berarti. Permukiman warga tetap berada di tepian sungai dan kalaupun terdapat penambahan rumah, oleh karena keterbatasan lahan di tepi sungai maka dibangun di belakang permukiman yang ada di tepi sungai.

Sungai masih tetap dimanfaatkan oleh warga Desa Talingke. Oleh karena itu keberadaan batang/jamban masih dengan mudah ditemui di sepanjang sungai. Interaksi dengan para pedagang (kapal dagang, pengepul rotan, karet, dan lain-lain), aktivitas sehari-hari warga sepenuhnya masih dipusatkan di sungai. Demikian juga mayoritas warga masih mengandalkan transportasi air. Namun seiring dengan kemampuan membeli kendaraan bermotor, warga semakin sering mengakses jalan darat sebagai sarana mobilitas meskipun kondisi jalan darat belum sepenuhnya dapat diakses.

Kedua desa menunjukkan reaksi yang berbeda dalam menanggapi pembangunan. Warga Desa Pangi menanggapi pembangunan jalan raya dengan mengubah orientasi hidup yang awalnya ke sungai menjadi ke darat. Sementara dengan pembangunan jalan yang belum selesai, warga Desa Talingke masih tetap berorientasi ke sungai. Bahkan dalam hal mata pencaharian, warga Desa Talingke justru semakin berorientasi ke sungai karena sungai dipandang memiliki nilai ekonomi lebih tinggi dibandingkan dengan sumber daya yang ada di darat.

Dari gambaran kedua desa ini memperlihatkan bagaimana pembangunan mengubah ruang hidup masyarakat dalam tataran yang berbeda.
Poerwanto (2010:157) menyebutkan bahwa pembangunan merupakan perubahan dan kebudayaan adalah upaya manusia untuk menyempurnakan diri dalam kondisi kehidupannya.

\section{Makna Sungai}

Bagi masyarakat yang tinggal di tepian sungai, sungai memiliki fungsi penting dalam kehidupan mereka. Tabel 1 memperlihatkan bagaimana sungai memiliki beragam fungsi bagi masyarakat Desa Talingke. Sungai dipandang bukan hanya sekedar bentang alam semata namun sungai memiliki makna penting dalam kehidupan. Sungai adalah sumber kehidupan dimana masyarakat bisa memenuhi kebutuhan mereka dari sumber daya yang terkandung didalamnya. Sungai juga dimaknai sebagai tempat dimana masyarakat dapat memusatkan seluruh aktivitas hidup dan tempat dimana mereka saling berinteraksi.

Sebagai sebuah bentang alam, bagi masyarakat Desa Talingke sungai merupakan "tempat biasa yang tidak biasa”. Sungai merupakan tempat yang biasa mereka manfaatkan namun menjadi "tempat yang tidak biasa" karena merupakan tempat tinggal Jatak atau $J t^{30}{ }^{30}$. Beberapa warga yang merasa memiliki keterkaitan dengan Jatak masih sering memberikan sesaji ke sungai sebagai persembahan kepada Jatak agar tidak mengganggu kehidupan mereka. Salah satunya adalah Mama Nonoy (45 tahun). Pada saat pengumpulan data dilakukan pada tanggal 24 Maret 2016, Mama Nonoy bercerita jika anaknya memiliki

${ }^{30}$ Makhluk penghuni air berwujud buaya. 
hubungan dengan Jata sehingga di saatsaat tertentu ia harus memberikan sesaji kepada Jata agar tidak terjadi apa-apa dengan anaknya. Menurut Mama Nonoy jika ia lupa memberikan sesaji kepada Jata maka anak laki-lakinya tersebut akan bertindak seperti orang kesurupan. Namun kondisi tersebut akan sembuh ketika sang ibu memberikan sesaji kepada Jata.

Selain percaya kepada Jata, salah satu mitos yang hingga kini masih dipercaya kebenarannya oleh warga Talingke yaitu jika ada yang membawa makanan dan minuman melintasi Sungai Katingan maka mereka harus memberikan sedikit "makanan" dengan cara membuang sedikit makanan yang dibawa sebagai permohonan ijin melintasi sungai kepada para penghuni sungai. Warga percaya jika hal ini tidak dilakukan maka gethek, alkon atau ces yang digunakan bisa terbalik. Oleh karena itu para penjual makanan dan minuman yang datang berdagang ke wilayah Desa Talingke tak segan untuk sekadar memberikan sedikit "makanan" ketika melintasi Sungai Katingan.

Mitos-mitos tentang sungai masih dihormati dan dipatuhi masyarakat namun upacara-upacara yang dahulu pernah dilakukan sebelum memeluk Islam kini tidak lagi dilakukan. Sebagai pemeluk agama Islam, segala upacara siklus hidup dilakukan menurut ajaran agama. Masyarakat Talingke juga tidak lagi menggunakan sungai sebagai orientasi dan pedoman hidup dalam pembangunan rumah dan pembagian ruang. Ajaran agama dan keterbatasan lahan permukiman menjadikan masyarakat tidak lagi menggunakan sungai sebagai konsep dalam pembangunan rumah dan pembagian ruang. Demikian juga konsep ngaju-ngawa hanya sebatas untuk penyebutan arah semata.

Seiring dengan perubahan mata pencaharian dari petani rotan dan petani karet menjadi penambang emas, sungai memiliki makna lebih. Sungai dipandang memiliki nilai ekonomi yang tinggi dimana kandungan emas di sungai mendatangkan keuntungan ekonomi bagi warga Talingke sejak tahun 2014.

Sementara di Desa Pangi, aktivitas pertambangan emas di sungai sudah dimulai lebih awal yaitu tahun 1990an. Saat ini meskipun aktivitas pertambangan emas di sungai masih ada namun ada kecenderungan para penambang mulai beraktivitas di darat dengan menyasar kebun/ladang karet warga.

Aktivitas sehari-hari warga Desa Pangi memang tidak lagi dilakukan di sungai. Saat ini pemandangan yang dapat ditemui di Sungai Kahayan hanyalah aktivitas para penambang emas di lanting dan lalu lalang ces milik penambang serta warga yang menuju ke kebun. Meski tidak lagi menjadikan sungai sebagai pusat aktivitas dan interaksi namun bagi warga Pangi, sungai memiliki makna lebih. Sungai bukan hanya sumber penghidupan warga dengan adanya kandungan emas di dalamnya namun sungai telah menjadi bagian dari kosmologi. 
Handep Jurnal Sejarah dan Budaya Vol. 5, No. 1, Desember 2021, hlm. 69-96

\begin{tabular}{|c|c|c|}
\hline Makna Sungai & $\begin{array}{l}\text { Desa Talingke } \\
\end{array}$ & Desa Pangi \\
\hline $\begin{array}{l}\text { Pusat aktivitas dan interaksi } \\
\text { warga }\end{array}$ & $\begin{array}{l}\text { MCK, sumber protein, sumber } \\
\text { air bersih, tempat } \\
\text { menambatkan ces, tempat } \\
\text { berlabuh kapal dagang, dan } \\
\text { lain-lain }\end{array}$ & \\
\hline Sumber penghidupan & $\begin{array}{l}\text { Sumber mata pencaharian } 90 \% \\
\text { warga desa sebagai penambang } \\
\text { emas di sungai }\end{array}$ & $\begin{array}{l}\text { Salah satu mata pencaharian warga } \\
\text { yang banyak digeluti yaitu sebagai } \\
\text { penambang emas }\end{array}$ \\
\hline $\begin{array}{l}\text { Tempat tinggal makhluk } \\
\text { adikodrati }\end{array}$ & $\begin{array}{l}\text { Tempat tinggal Jatak dan } \\
\text { makhluk lain }\end{array}$ & $\begin{array}{l}\text {-Tempat tinggal Kanarihing Ganan } \\
\text { Danum dan mahluk air lain } \\
\text {-Representasi dunia bawah }\end{array}$ \\
\hline Orientasi rumah dan ruang & - & $\begin{array}{l}\text { Tata letak rumah dan ruang } \\
\text { mengacu pada konsep hulu-hilir } \\
\text { (ngaju-ngawa) }\end{array}$ \\
\hline $\begin{array}{l}\text { Pedoman pendirian bangunan } \\
\text { sakral }\end{array}$ & - & $\begin{array}{l}\text { Pendirian sandung dan sapundu } \\
\text { mengacu pada arah dan letak } \\
\text { sungai }\end{array}$ \\
\hline $\begin{array}{l}\text { Tempat pelaksanaan upacara dan } \\
\text { pemberian sesaji }\end{array}$ & $\begin{array}{l}\text { Tempat pemberian sesaji } \\
\text { kepada Jata dan makhluk } \\
\text { sungai lain bagi warga yang } \\
\text { percaya }\end{array}$ & $\begin{array}{l}\text { - Tempat pelaksanaan upacara } \\
\text { Nahunan, Paleteng Malambung, } \\
\text { dan Mambaleh Bunu Pada } \\
\text { Kanarihing Ganan Danum } \\
\text { - Tempat pemberian sesaji kepada } \\
\text { penghuni alam bawah }\end{array}$ \\
\hline Penyebutan arah & Hulu-hilir & $\begin{array}{l}\text { - Ngaju-ngawa (hulu-hilir) untuk } \\
\text { menyebut arah utara dan selatan } \\
\text { - Ngambu-ngiwa (tinggi-rendah) } \\
\text { untuk menyebut arah timur dan } \\
\text { barat (arah timbul dan } \\
\text { tenggelamnya matahari) } \\
\end{array}$ \\
\hline $\begin{array}{l}\text { Danum Kaharingan (Air } \\
\text { Kehidupan) }\end{array}$ & - & $\begin{array}{l}\text { Air sungai adalah air kehidupan di } \\
\text { dalamnya terkandung seluruh apa } \\
\text { yang ada dalam hidup manusia, } \\
\text { mengandung khasiat yang baik }\end{array}$ \\
\hline
\end{tabular}

Tabel 2. Makna sungai bagi masyarakat Desa Talinge dan Desa Pangi. Sumber: olah data lapangan.

Dari tabel 2 tersebut terlihat bahwa bagi warga Desa Pangi sungai tidak lagi bermakna "secara fisik" namun sungai adalah bagian dari kosmologi mereka. Sebaliknya bagi warga Desa Talingke, sungai masih dimaknai "secara fisik" karena sumber daya sungai menjadi tumpuan warga untuk melangsungkan kehidupannya. Perbedaan pemaknaan terhadap sungai tersebut disebabkan karena perbedaan karakteristik masyarakat Desa Pangi dan Desa Talingke.

Secara identitas etnis, baik masyarakat Desa Talingke maupun masyarakat Desa Pangi berasal dari suku Dayak Ngaju. Namun dilihat dari agama yang dianut oleh masyarakatnya terdapat perbedaan yang cukup signifikan. Hampir seluruh warga Desa Talingke beragama Islam sehingga mereka tidak lagi menjalankan adat istiadat orang Ngaju. Upacara-upacara adat, ritual orang Ngaju yang berkaitan dengan siklus hidup manusia ataupun upacara-upacara yang diajarkan oleh leluhur tidak lagi dilakukan. Selain upacara, bangunan sakral seperti sandung dan sapundu serta simbolsimbol Kaharingan juga tidak ditemukan di desa ini.

Jika masyarakat Desa Talingke hampir seluruhnya memeluk Islam maka agama dan keyakinan masyarakat 
Desa Pangi lebih beragam. Mereka memeluk agama Islam, Kristen, Katholik, serta Kaharingan yang merupakan agama lokal Orang Ngaju. Meski tidak dipeluk oleh mayoritas warga Desa Pangi, namun nuansa Kaharingan sangat terasa di desa ini. Simbol-simbol Kaharingan, tempat ibadah pemeluk Kaharingan, bangunan sakral banyak ditemukan di desa ini. Demikian juga pelaksanaan upacaraupacara adat dan tradisi Kaharingan rutin dilaksanakan di desa dengan dipimpin oleh para basir.

Dalam kosmologi pemeluk Kaharingan, sungai memiliki makna yang sangat luas. Hulu sungai dalam sejarah manusia menurut ajaran nenek moyang menjadi tempat dimana untuk pertama kalinya manusia membangun kehidupannya. Oleh karena itu sungai menjadi bagian penting dalam kehidupan orang Ngaju dari lahir hingga meninggal ${ }^{31}$. Sungai dan alam di bawahnya juga diyakini berhubungan dengan hal-hal yang bersifat adikodrati ${ }^{32}$ sehingga sesaji yang diberikan dalam upacara dan ritual ditujukan untuk mereka sebagai

${ }^{31}$ Saat pemeluk Kaharingan meninggal dunia, maka biasanya roh orang yang meninggal akan ditunjukkan kilas balik kehidupannya dari hulu sungai menuju hilir (disebut dengan ritual Ngalingguk). Wilayah hulu menjadi awal kilas balik kehidupan orang yang sudah meninggal karena orang Ngaju percaya jika nenek moyang manusia membangun rumah untuk pertama kali di bagian hulu sungai.

32 Dalam pandangan warga Desa Pangi, sungai dan alam di bawahnya dihuni berbagai makhluk adikodrati seperti Tambun, Naga, Nabi air, dan Jata yang dipercaya berkarakter baik serta Kanarihing Ganan Danum yang berkarakter jahat. bentuk penghormatan. Sebagai tempat di mana mahluk adikodrati berada, sungai juga menjadi tempat pelaksanaan upacara tertentu. Semua yang dilakukan merupakan bagian dari ajaran Kaharingan.

Berkaitan dengan keberadaan mahluk adikodrati, para penambang emas di Sungai Kahayan juga mengakui keberadaan mahluk penghuni sungai dan alam di bawahnya. Pada saat akan nyedot di lokasi baru atau sudah berusaha menambang emas namun tidak mendapatkan hasil yang diharapkan maka seringkali para penambang memberikan sesaji ${ }^{33}$. Pengakuan akan keberadaan kekuatan supranatural memberikan makna kepada suatu tempat (place) yang dipandang sakral karena dianggap sebagai tempat kediaman khusus bagi kekuatan adikodrati (Crowe dalam Harsyakti dan Mulyadi 2014). Lebih lanjut dikatakan bahwa mengenali makna suatu tempat merupakan hal penting bagi manusia untuk memudahkan dalam mengatur dan menyelaraskan perikehidupannya.

Salah satu cara warga dalam mengatur dan menyelaraskan perikehidupannya dengan alam dapat dilihat dari bagaimana warga Desa Pangi menjadikan sungai sebagai sumber orientasi dan pedoman hidup. Seiring dengan pembangunan jalan lintas, sungai tetap dijadikan sebagai pedoman dan orientasi hidup warga Desa Pangi. Hanya saja dalam praktiknya seringkali terjadi pedoman dan aturan tersebut "dimodifikasi" mengikuti perubahan ruang yang terjadi. 
Handep Jurnal Sejarah dan Budaya Vol. 5, No. 1, Desember 2021, hlm. 69-96

a. Konsep Ngaju - Ngawa dalam Aturan Tata Letak Rumah, Ruang dan Bangunan Sakral (Sandung dan Sapundu)

Idealnya, dalam posisi sejajar, letak rumah atau kamar orang yang lebih muda berada di sebelah hulu rumah orang yang lebih tua. Mereka percaya jika energi mengalir dari ngaju ke ngawa (hulu ke hilir) seperti halnya air yang mengalir di sungai. Jika posisi rumah atau kamar tidak sesuai dengan aturan ideal tersebut maka orang yang lebih muda harus menyangga aliran yang tua. Apabila hal ini terjadi dikhawatirkan orang yang lebih muda tidak akan kuat sehingga mereka dapat terkena sakit, sulit rezeki ${ }^{34}$, atau meninggal. Kepercayaan tentang aliran energi ini juga berlaku untuk dapur dan letak tungku. Dapur yang identik dengan energi "panas" secara ideal seharusnya ditempatkan di dalam rumah di sisi hilir agar aliran panas dari dapur tidak mengenai orang yang tinggal di rumah tersebut.

Pembangunan jalan raya dan juga keterbatasan tanah yang dimiliki menjadikan aturan ideal dimodifikasi. Dalam membangun rumah, seringkali rumah orang yang lebih muda dibangun di sebelah hilir orang yang lebih tua. Cara ini bisa dilakukan dengan catatan letak rumah orang yang muda agak dimajukan atau dimundurkan sehingga aliran energi tetap berjalan lancar (anak yang muda tidak perlu menyangga aliran energi yang lebih tua).

${ }^{34}$ Rezeki orang yang lebih muda akan berkurang karena kalah dengan posisi orang tua yang lebih tinggi.
Penerapan konsep ngaju-ngawa juga dapat dilihat dalam pendirian sandung dan sapundu yang merupakan bangunan sakral. Sandung dan Sapundu biasanya dibangun bersandingan dan idealnya dibangun di sebelah ngawa atau hilir rumah keluarga orang yang meninggal. Dalam kepercayaan mereka, orang yang telah meninggal (meski umur lebih muda) dianggap sudah lebih tua daripada penghuni rumah sehingga orang yang "dianggap tua" diletakkan di sebelah ngawa. Selain itu pembangunan sapundu juga tidak boleh diletakkan menghadap ke arah rumah. Oleh karena itu di masa lalu, banyak sapundu yang menghadap sungai karena rumah-rumah warga dibangun menghadap ke sungai ${ }^{35}$.

Saat ini banyak rumah warga yang telah dibangun di tepi jalan lintas sehingga pembangunan sandung dan sapundu juga disesuaikan dengan kondisi tersebut. Sesuai aturan, pendirian sandung tidak boleh menghadap ke rumah pemiliknya, maka dari itu sapundu didirikan menghadap jalan lintas agar tidak menghadap ke rumah warga. Meski arah hadap tidak lagi mengikuti/mengarah ke sungai namun dari tata letak, sandung dan sapundu masih mengikuti konsep ngaju-ngawa.

\section{b. Tempat Pelaksanaan Upacara}

Dalam ajaran Kaharingan, manusia memiliki kewajiban untuk menjaga keseimbangan alam karena alam

\footnotetext{
${ }^{35}$ Aturan ini lebih untuk ke arah hadap sapundu sehingga di Desa Pangi ditemukan sandung dan sapundu yang berbeda arah. Sandung menghadap ke permukiman warga sedangkan sapundu tetap menghadap ke arah sungai atau membelakangi permukiman warga.
} 
dipercaya juga dihuni oleh mahlukmahluk/roh-roh lain. Kaharingan mengajarkan bahwa "Tuhan disembah, leluhur dihormati, alam disahabati". Untuk tetap menjaga hubungan yang baik dengan ketiga hal tersebut, maka dilakukan beragam upacara dari upacara yang berkaitan dengan siklus hidup, upacara individu hingga upacara untuk kepentingan bersama/komunal. Di antara berbagai upacara tersebut, beberapa upacara dilakukan di sungai seperti upacara Nahunan ${ }^{36}$, Paleteng Malambung $^{37}$, dan Mambaleh Bunu Pada Kanarihing Ganan Danum ${ }^{38}$.

Pada upacara Nahunan, bayi yang akan diberi nama biasanya dimandikan di sungai. Pada upacara nahunan, bidan kampung menggendong si anak menuju ke sungai yang mengalir di dekat rumah. Sebelum dimandikan, bidan akan mengiris-iris air sungai dengan parang serta melepaskan patung pasak berisi ketupat dan telur yang ditusukkan ke air untuk memberikan makanan

36 Upacara pemberian nama pada anak.

${ }^{37}$ Upacara ini untuk membayar hajat yang telah diucapkan oleh seorang Kaharingan atau orang yang telah bersahut kepada Jata, penguasa alam bawah. Dalam kosmologi pemeluk Kaharingan, sungai dipercaya menjadi pintu masuk ke alam bawah, tempat tinggal Jata. Oleh karena itu jika ingin memberikan sesaji kepada Jata atau kepada penghuni alam bawah lainnya bisa dilakukan di sungai.

38 Upacara ini dilakukan untuk membalas bunuh pada Kanarihing (penguasa air). Upacara ini dilakukan jika terjadi kecelakaan di sungai yang mengakibatkan seseorang meninggal dan untuk mengembalikan hubungan yang baik antara manusia dan Kanarihing maka dilakukan upacara ini dengan harapan kejadian serupa tidak akan berulang kembali. kepada para penunggu air, salah satunya kepada Kanarihing ${ }^{39}$. Setelah itu bidan akan memandikan bayi dilanjutkan dengan pencelupan pangkal pohon sawang yang diikatkan pada tombak ke air oleh ayah bayi dan kemudian diteteskan ke kepala anak sebanyak tujuh atau lima kali ${ }^{40}$. Penetesan air ini sebagai simbol bahwa anak tersebut mandi nyalung kaharingan belum (mandi air suci). Sesudah dimandikan, bidan bersama anak akan kembali ke rumah untuk melanjutkan ritual di rumah.

Saat ini ritual memandikan anak atau bayi pada upacara Nahunan tidak lagi harus dilakukan di sungai. Ritual memandikan bisa dilakukan di depan rumah dengan menggunakan sangkok (ember besar) dengan catatan air yang digunakan harus berasal dari sumber air yang mengalir (sungai, parit, dan lain-lain). Oleh karena bayi tidak dimandikan langsung pada air yang mengalir maka yang digunakan harus disucikan dengan menggunakan bungabunga yang ditaburkan di dalam sangkok. Jika hal tersebut dilakukan maka tidak mengurangi makna dari ritual tersebut. Untuk Upacara Paleteng Malambung dan Mambaleh Bunu Pada Kanarihing Ganan Danum harus tetap dilaksanakan di sungai karena pelaksanaan kedua upacara ini berkaitan dengan penghuni sungai dan alam di bawahnya.

\footnotetext{
${ }^{39}$ Pemberian makanan ini bertujuan agar Kanarirhing tidak mengganggu berjalannya Upacara Nahunan serta mengganggu kehidupan si anak.

${ }^{40}$ Hal yang sama juga dilakukan ketika menggunakan sangkok.
} 
Handep Jurnal Sejarah dan Budaya Vol. 5, No. 1, Desember 2021, hlm. 69-96

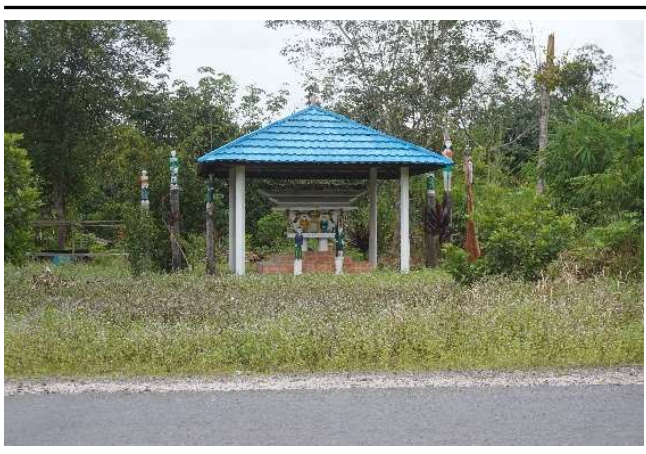

Gambar 9. Sandung dan Sapundu menghadap jalan. Sumber: dokumentasi penulis.

Seiring dengan perubahan ruang hidup, masyarakat yang tinggal di tepian sungai berusaha menyesuaikan diri dengan perubahan tersebut dengan melakukan modifikasi dalam tata letak rumah dan ruang, arah bangunan sakral dan perubahan tempat pelaksanaan upacara untuk menyiasati perubahan ruang yang terjadi. Kebudayaan mengenal ruang dan tempat tumbuh dan berkembang serta mengalami perubahan dan bahwa suatu perubahan yang terjadi mengharuskan perlunya memodifikasi tingkah laku (Poerwanto 2010:139-140). Modifikasi penerapan konsep sungai dalam kehidupan seharihari merupakan bentuk penyesuaian terhadap aturan ideal yang ada. Mereka beradaptasi, dengan tetap memperhatikan nilai-nilai yang dianut dan situasi lingkungannya. Hal ini seperti yang disebut oleh Bennet dalam Kutanagara (2014:25-27) dimana dalam adaptasi masyarakat tetap memperhatikan norma dan situasi lingkungannya meski adakalanya manusia memanipulasi semua itu dengan kemampuan akalnya.

\section{SIMPULAN}

Sungai memiliki makna yang berbeda bagi masyarakat Desa Pangi dan Desa
Talingke. Sebagai masyarakat yang sama-sama tumbuh dan berkembang di wilayah tepian sungai, pada perkembangannya kedua desa memaknai sungai secara berbeda.

Masyarakat Desa Pangi dengan jumlah pemeluk Kaharingan yang cukup banyak, memaknai sungai bukan lagi secara "fisik" namun pada "konsep" yang terkandung di dalamnya. Nilai-nilai dan konsep yang tersebut menjadi orientasi dan pedoman hidup masyarakat Ngaju dalam kehidupan sehari-hari.

Seiring kemudahan akses dengan adanya pembangunan jalan lintas, masyarakat dan pemerintah menanggapi pembangunan tersebut dengan membangun rumah, tempat usaha dan fasilitas umum mendekati jalan lintas. Pembangunan yang dilakukan masyarakat dan pemerintah menjadikan ruang hidup masyarakat Desa Pangi berubah. Secara spasial, ruang hidup mereka semakin luas dan mengarah ke darat. Sungai menjadi tempat yang semakin ditinggalkan. Namun demikian, dalam ruang yang telah berubah, nilai dan konsep sungai masih tetap diterapkan oleh masyarakat meskipun dalam praktiknya terjadi beberapa modifikasi terhadap aturan ideal untuk menyesuaikan dengan kondisi yang ada.

Sebaliknya, masyarakat Desa Talingke masih sepenuhnya memaknai sungai secara "fisik". Pembangunan jalan yang belum sepenuhnya selesai menjadikan masyarakat tetap mengandalkan sungai untuk memenuhi kebutuhan hidup sehari-hari. Akses jalan darat masih belum memberikan kemudahan bagi masyarakat Desa Talingke sebaliknya akses ke sungai 
dirasakan jauh lebih mudah. Oleh karena itu masyarakat Desa Talingke masih memaknai sungai "secara fisik". Sedangkan secara "nonfisik" sungai hanya dimaknai sebagai tempat tinggal Jatak. Sebagai pemeluk agama Islam, masyarakat Desa Talingke tidak lagi menjalankan adat istiadat (upacara, ritual, dan lain-lain) orang Ngaju.

Pembangunan jalan yang belum sempurna ditanggapi "dingin" baik oleh masyarakat maupun pemerintah desa. Secara spasial, hampir tidak ada perubahan berarti dalam ruang hidup masyarakat. Permukiman, fasilitas umum semua masih terpusat di tepian sungai. Hanya saja sejak pertambangan emas di sungai marak dan berhasil mendorong kehidupan ekonomi, masyarakat mulai mengakses jalan darat yang belum sepenuhnya bisa diakses.

Dari kedua desa ini dapat dilihat bahwa laju pembangunan jalan darat, karakteristik lokasi dan karakteristik masyarakat yang berbeda menjadikan sungai dimaknai secara berbeda pula.

\section{DAFTAR SUMBER}

Badan Pusat Statistik Kalimantan Tengah. 2021. Kalimantan Tengah dalam Angka Tahun 2021. Diunduh 8 September 2021 (https://kalteng. bps.go.id/publication/2021/02/26/ 149e87d54217d42942544610/ provinsi-kalimantan-tengah-dalam angka-2021.html.

Badan Pusat Statistik Kabupaten Katingan. 2020. Tasik Payawan dalam Angka 2020. Diunduh 13 April 2020 (katingankab.bps.go.id/ publication/2019/09/26.
Fahrianoor dan Andika Sanjaya. 2021. "Konsep Batang Banyu pada Masyarakat Tepian Sungai dalam Menjaga Keberlanjutan Sungai di Kalimantan Selatan." Prosiding, Seminar Nasional Lingkungan Lahan Basah 6(3), Lembaga Penelitian dan Pengabdian kepada Masyarakat, Universitas Lambung Mangkurat.

Hamidah N, R. Rijanta, Bakti Setiawan, dan Muh. Aris Marfai (2014). "Kajian Transportasi Sungai untuk Menghidupkan Kawasan Tepian Sungai Kahayan Kota Palangkaraya”. Tata Loka 16(1): 117.

Harysakti, Ave dan Lalu Mulyadi. 2014. "Penelusuran Genius Loci pada Permukiman Suku Dayak Ngaju di Kalimantan Tengah. Jurnal Spectra No. 24, Vol XII.

Hartatik. 2004. "Situs dan Budaya Sungai: Prospek Wisata di Kalimantan" dalam Sungai dan Kehidupan Masyarakat di Kalimantan disunting oleh Gunadi Kasnowihardjo dkk. Banjarbaru: IAAI Komda Kalimantan. .2017a. JejakBudaya Dayak Meratus dalam Perspektif Etnoreligi. Yogyakarta : Ombak. . 2017b. "Sungai Barito dalam Persebaran Suku Dayak di Kalimantan Bagian Tenggara". Naditira Widya 11(2): 149-164.

Johansen, Poltak., Donatianus BSEP, dan Albertus. 2017. Kebudayaan 
Handep Jurnal Sejarah dan Budaya Vol. 5, No. 1, Desember 2021, hlm. 69-96

Sungai pada Komunitas Dayak Pompakng. Yogyakarta: Kepel Press.

Kasnowihardjo, Gunadi, Wasita, dan Andi Nuralang, (ed.). 2004. Sungai dan Kehidupan Masyarakat di Kalimantan. Banjarbaru: IAAI Komda Kalimantan.

Kutanegara, Pande Made. 2014. Manusia, Lingkungan dan Sungai: Transformasi Sosial Kehidupan Masyarakat Sempadan Sungai Code. Yogyakarta: Ombak.

Luardini, Maria Arina. 2008. "Makna dan Nilai yang Terkandung dalam Teks Legenda Dayak Ngaju". Linguistika 15(28): 1-28.

Mentayani, Ira. 2019. "Identitas dan Eksistensi Permukiman Tepi Sungai di Banjarmasin." Prosiding, Seminar Nasional Lingkungan Lahan Basah 4(3):497-502 Lembaga Penelitian dan Pengabdian kepada Masyarakat, Universitas Lambung Mangkurat.

Prastiwi, Septi Dhanik, Ari Wahyudi dan Jonathan Philip Thomas. 2016. Pertambangan Emas di Sungai Katingan: Perubahan Fungsi Sungai Bagi Masyarakat Dayak Ngaju. Yogyakarta: Diva Press.

Prastiwi, Septi Dhanik dan Galuh Bayuardi. 2017. Sungai dalam Kosmologi Orang Ngaju. Pontianak: Kepel Press.

Poerwanto, Hari. 2010. Kebudayaan dan Lingkungan dalam Perspektif
Antropologi. Yogyakarta: Pustaka Pelajar.

Purba, Juniar., Poltak Johansen dan Donatianus BSEP. 2020. Budaya Sungai pada Masyarakat Sintang. Bandung : Media Jaya Abadi.

Putro, Jawas Dwi dan M. Nurhamsah. 2015. "Pola Permukiman Tepian Air Studi Kasus: Desa Sepuk Laut, Punggur Besar dan Tanjung Saleh Kecamatan Sungai Kakap, Kabupaten Kubu Raya”. Langkau Betang 2(1):65-76.

Rahmayani, Any., Yusri Darmadi, dan Andang Firmansyah. Integrasi Ekonomi di Sungai Kapuas pada 1900-1942. Yogyakarta: Diva Press.

Riwut, Nila (ed). 2007. Kalimantan Membangun Alam dan Kebudayaan. Yogyakarta : NR Publishing.

2015. Manaser Panatau Tatu Hiang Menyelami Kekayaan Leluhur. Yogyakarta : NR Publishing.

Rochgiyanti. 2011. "Fungsi Sungai Bagi Masyarakat di Tepian Sungai Kuin Kota Banjarmasin”. Jurnal Komunitas 3(1):51-59.

Rusan, Ahim S dkk, 2006. Sejarah Kalimantan Tengah, Palangkaraya: Lembaga Penelitian Universitas Palangkaraya dan Pemerintah Provinsi Kalimantan Tengah. 
Scharer, Hans. 1963. Ngaju Religion

the Conception of god Among a South Borneo People. Holland: Publication Commission and Financed the Netherland Institute For International.

Subiyakto, Bambang dan Djoko Suryo. 2001. "Pelayaran Sungai di Kalimantan Tenggara: Tinjauan Historis tentang Transportasi Air Abad XIX". Sosiohumanika $14(1): 25-37$.

Surnaningsih. 2017. Karakter Permukiman Lahan Basah Abad VI-XV Maseho di DAS Barito. Jurnal Kapata Arkeologi 13(1):109-130.

Wijanarka. 2008. Desain Tepi Sungai: Belajar dari Kawasan Tepi Sungai Kahayan Palangkaraya. Yogyakarta : Ombak.

Wawancara. Esna. Desa Talingke, 19 Maret 2016

Wawancara. Mama Nonoy. Desa Talingke, 24 Maret 2016.

Wawancara. Kusnadi. Desa Pangi, 16 Maret 2017. 
